\title{
Analysis of Mental Connotation of Beethoven's Fifth Symphony (Fate) from the Angle of Improving College Students' Aesthetic Quality
}

\author{
Yingping Zhu \\ Music and Dance College \\ Zhongzhou University \\ Zhengzhou, Henan 450044.China \\ Zhuyingping3168@163.com
}

\begin{abstract}
Beethoven's Fifth Symphony (Fate) is one of his the most outstanding representative works which expresses Beethoven's unbending spirit of life long struggle with the fate. From the angle of improving college students' aesthetic quality, with music pedagogy, psychology, philosophy and aesthetics as the theoretical support, with common college students as the research object, this thesis aims at analyzing mental connotation of Beethoven's fifth symphony (fate), in order to enlighten contemporary college students to explore life philosophy and to set up the correct outlook on life and values.

Beethoven's "Fifth Symphony "(Fate) in C minor(hereinafter referred to as "Destiny Symphony"), is a sign that music turns from entertainment to the sublime in the period of classical time. This symphony not only dominates the music creation and music thoughts in the 19th century, but also produces profound impact on the social change of that era. Beethoven's symphony and Beethoven's spirit's inheritance and teaching have an important significance on enriching the spiritual world of contemporary college students and helping them set up the correct outlook on life and values. How to grasp the contemporary college students' thoughts, psychological characteristics and music accomplishment is the core problem we should solve in music appreciation class teaching. By music expression forms of Beethoven's Destiny Symphony, we try to reveal deeply its spiritual connotation to inspire college students' understanding of life philosophy.
\end{abstract}

Keywords: Beethoven; Fifth Symphony; Innovation; philosophy meaning; Ideology; Mental connotation

\section{THE INTERPRETATION OF INNOVATIVE, PHILOSOPHICAL, AND IDEOLOGICAL CONTENT OF DESTINY SYMPHONY}

Beethoven is a new generation of composer who is influenced by the French bourgeois revolution thought, and in his whole life, he yearns for the bourgeois ideal of the "freedom, equality, and fraternity". Before the creation of The Fourth Symphony in 1805, he began to meditate Destiny Symphony, and he finished it in 1808. The hero conception in "Destiny symphony" is the continuous and further developed hero image established in the "Third Symphony". He compares the setbacks, difficulties and pains, failures and hardships on the revolutionary road which human being would encounter in the life as "fate", and man should be the master fate, not attached to the mercy of fate. Man should have high sense of responsibility for society. The struggle is the only choice to pull the binding of the chains of fate, light the torch of freedom, and march towards joy, happiness, brightness and victory.
The struggle theme of "Destiny Symphony" is originally the prototype of tragedy in the Enlightenment period. In classical tragedies and closely associated Gluck music drama, the contradiction between man and fate is irreconcilable. Yet severely cruel fate image is often depicted as inevitable and the victory of man suddenly happens by forces from outside. However, Beethoven reforms the traditional theme and processes it with a new method. That is, he makes the man's will transformed to action. In his symphony, man's victory is von by the desperate struggle with violence of fate. What "Destiny Symphony" extols is no longer the idealized heroes in "Hero Symphony", but the hero group emerged in the tide of battle. What "Hero Symphony" extols is the hero himself, but what "Destiny Symphony" extols is heroic mass of people.

In order to reflect such magnificent conception, he reformed the symphony structure made by predecessors. He makes every chapter, every paragraph, and every line in the symphony to obey unified conception of this symphony, and made the four stanzas into an integral whole. In order to strengthen the whole divertimento, Beethoven boldly broke the boundaries between different stanzas and formed continuous performance between different stanzas. In order to enhance the connection between the different stanzas, Beethoven initially created method of theme-memory, that is, in the finale the creator recalled the main theme of former stanzas. Beethoven carried on bold reform and innovation in creation style, testure, harmonic, band preparation and technique. Although the four stanzas expressed different themes, speeds, styles and images, they reflected the progressed struggle from different sides, which expressed the main theme of "breaking through the darkness for light, winning the victory through the struggle."

The first stanza is written in sonata form, which is the full expression of "will to fight". On creation, first of all, Beethoven abandons usual practice with the beginning of large section of the adagio play. He directly plays the fate theme of shocking people's hearts with all strings and woodwind with ff: (ab

This is the core of the whole song. When it first appears, it sounds like a powerful thunderbolt, leaving people impression of authority, 
fierce, the sudden feeling. It symbolizes darkness enveloped the earth. These four notes are called "the leading motive" of whole song. They go throughout the four stanzas to become motivation and adhesive promoting the organic unity of the whole song. Vice theme is: It has lyrical style, kind, cheerful singing, which is a symbol of the bright prospect of future. And people are yearning for happiness and joy. It contains a strong potential, and later develops into theme of "hero" which can compete with "fate" and finally win over destiny. Beethoven applies dialectical thought into sonata form, and chooses dark and light as rivals. From presentation part, exhibition part to reproduction part, the main theme of fate (majesty, fierce, dark) is always accompanied by vice theme (bright and beautiful future) from beginning to end in the development and changes. After dramatic conflicts, the theme of fate makes the contrast of the images in the process of opposite struggle to have mutual influence, mutual restriction, and mutual transformation. From initially strong, hard bruising battle with hero, Destiny Theme transforms into a seemingly strong, dominant, screaming will of fight, which ultimately reflects that the hero won over the fate. If the main part of the song is a serious deterrent power in reality, then the deputy part of the song is the ideal of happiness for light. The hero is able to fight with fate toughly because it is full of hope for the future. The two elements from sharp contrasts but they have inner links, which set up the dialectical relationship between each other.

The second stanza expresses "philosophical thinking in struggle clearance", and here Beethoven was the first to adopt the dual variations to write it. It is called "big variations". Two themes are close to the mass music genre in the era of French revolution, forming the main song and deputy song, chorus and lead contrasting relationship. The first theme is like lead vocalist, intrinsic and implicative, a symbol of the personal thinking of fate in the future. The second theme is like chorus, mighty and powerful. It has courageously soaring up heroic spirit, a symbol of hero image of people. In the development of the variation of the two themes, the second theme has always maintained the original image of mass hero. And the first theme in variation, step by step is away from individual, meditation image, moving closer to the second topic. In last variation, the first topic finally merged into the torrent of people team in the second topic, and became the hero image with firm power. In the development of music image, Beethoven profoundly reveals his philosophical ideal, that is, in the struggle with fate, personal ideal and struggle must be combined with the masses of the people in order to win the final victory.

The third stanza expresses "the process of will transforming into action", it is a farcicality song written in the trilogy type. This stanza makes a meticulous depiction of psychological activity process from another aspect about doubt, hesitation, uncertainty, cheering up, and firm fight faith. Fate dominated motivation undergoes three changes.

The first part of the music covers three factors. At first, the bass strings play the theme of meditation. Then, viola and violin and woodwind instruments play in trance and hesitation tone. Finally, horn toots (a) seemingly powerful fate theme. It reminds people that the road is bumpy, the future is not flat. With slightly trance, and hesitation, "destiny" will fight back. After three rounds of alternation, the first part expresses man's inner conflict and change when facing the destiny. Finally, doubt theme gradually becomes strong and enhances confidence. The second part plays strong dance tone by the string bass tones of area, and then develops with imitation in the treble area and forms social dancing scenes. It symbolizes people's firm defiance of the

"fate". Here fate theme transforms into people's united merry tone. The third stanza is the reproduction of the first stanza. The original fate theme is played lightly by string technique. The original arrogance has collapsed. It seems that destiny theme has been tamed totally. Gradually it moves from treble part to bass part, becoming faintly audible bass repetition: In the whole third part, Beethoven reveals profoundly his philosophical ideal. That is, man's fate should be grasped by himself. If you are weak, it will become strong. Or if you are strong, it will become weak. Instead of fearing the fate, you should fight against it..The fourth stanza depicts hundreds of millions of people cheering victory scene, written in sonata form. Beethoven makes bold innovation on the main part of presentation part by using two themes. The first theme is played by brass unison in $\mathrm{C}$ major, major chord uplink upward into progressive and syllable octave tonic technique. The song presents clear cloud and sunny scene. The second theme plays majesty marching sound by the horn and the wooden pipe. It complements each other with above victory tones and constitutes the hero theme describing triumphal procession. In this way, it deepens the grand scenes to break through the darkness to the light, the prestige of the people's triumph. The deputy theme plays victory festival dance by strings:

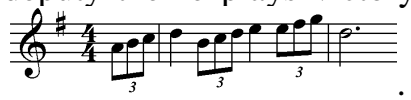

part of first stanza After winding development and change, it turns into deputy theme (dance) full of zest and joy. At this time, accompanied by people's singing and dancing, fate theme changed from the fate (ruler) of the people to "be ruled" by people.In expanding part, it is a combination of triumphal march with dance music, and dance themes appear more active, full of spirit. All the people are involved in the wave of the carnival. When the 
carnival rises to its climax, music suddenly ceases, and then it plays lightly the ghostly fate theme in the third stanza:

Here Beethoven, with theme memory technique, indicates people not to forget the hard-won victory in the moment of joy. In representation part, the victory horn is played again and people are immersed in a sea of joy. In the end part of the symphony, dance rhythm goes faster and faster, the joyful mood soars into the sky. In the end part the theme is constantly repeated, one could hear the last

variant of destiny theme: It is firm and forceful. It seems that thousands of people are cheering thunderously to celebrate the victory. Finally, this symphony ends in the ring of triumph songs. Beethoven's Destiny Symphony classically reflects the theme of winning through struggle, to break through the darkness to the light.

\section{REVELATION TO DESTINY SYMPHONY'S SPIRIT CONNOTATION}

"Destiny Symphony" creates a heroic music in the heroic age, and Beethoven, with his strong powerful music, celebrates an era ideal that "man should have the right to decide his own destiny in this era." From then on, entertainment function of music falls to the secondary status and the functions which express the human's deep emotions, thoughts, ideas, occupy the upper hand. Artists with independent spirit started to create music abiding their inner needs and impulse. From then on, the music won the true meaning of "noble". The two core concepts dominated the music creation and music thoughts in the 19th century, and produced profound impacts on the serious artists.

Beethoven's Destiny Symphony is one of the representative works which combines classical music and romantic music into one. The rise of romanticism music thoroughly enriches the connotation of elegant music from three aspects.

First, music is the product for personal inner impulse and spiritual needs. The creation of music should be independent, productive, not dominated by the nobility's demand in the classical period. Classical music predecessor Bach created music to his own heart in his old age. Mozart seems to struggle under the shadow of aristocratic demand and self demand creation in his lifetime. Haydn sacrificed the colorful passion and impulse for other's demand. But Beethoven completely emancipated the composer, at the same time completely freed the music. From then on, music is no longer a dinner entertainment and task, but the mission of the soul.

Secondly, music should express the complex emotions and one's own belief and will, the ideas to the world, and convey the nondescript self or mystical experience in the nature. So music becomes a mysterious language. On the one hand, it is related to literature, politics and society; on the other hand, it becomes philosophy in philosophy. In this cultural and spiritual atmosphere, elegant music challenges not only people's senses, but also people's mind. Beethoven brings classical music from the state of beauty to the lofty realm. Evaluation scales like "elegant", "sweet", "integrity", "moderate" are invalid in his mind, for he adds "serious" element greatly.

Thirdly, he created a kind of unprecedented hero style. In this hero style, the binary opposition in his inner world and its rich connotation is beyond classist. $\mathrm{He}$ has a true romantic soul, but his control and constraint to this opposition, by both willpower and elaborate design of art forms, is also beyond romanticist. He never had feeling flood and relaxation of artistic expression. Except Beethoven, no one can keep balance between one extreme (affection) to another (rationality and form) and lose the direction. Only Beethoven did it.

Beethoven is a great giant who can show his strong and rich emotion with great willpower and artistic expression. The power of his inner emotional conflict is rare in the history, and the capacity with great willpower and artistic expression to harness this conflict is also rare in the history. "Destiny Symphony" is an inspiring horn for a new world. He was a main prophet and creator of fantasy in the 19th century social changes. When he expressed his personal beliefs and ideals, at the same time, he cried out what his generation wanted to listen to.

\section{STUDENTS' INSPIRATION OF LIFE PHILOSOPHY FROM THE "DESTINY SYMPHONY"}

From the first stanza of "Destiny Symphony", we know that: People must prepare to face countless challenges and difficulties in their life. Facing difficulties, frustrations and failures, there should be indomitable willpower. To overcome difficulties and make great achievement, there must be a belief (target). With this belief, we can overcome difficulties and meet the challenges with full confidence.

From the second stanza of "Destiny Symphony", we know that: Personal struggle and success must be rooted in the nation's (the people) interest. With the integration of social value and benefit for the public, can we truly realize our personal values. On the way of life, only when we make a consideration of the society, other people, colleagues, friends, family, our life road can walk wider and wider. We should often ponder about our life. People's life is a process of practice pondering- practice again- a renew insight.

From the third stanza of "Destiny Symphony", we know that: we should dominate our own fate. We should not believe in fate, instead we should struggle against life. The fate is like a spring. If you are strong, it is weak; if you are weak, then it is strong. We should stick to our faith and grasp our "fate". People should not be the slave of fate.

From the fourth stanza of "Destiny Symphony", we know that: As long as we have firm faith and unite the masses to overcome difficulties and setbacks, we will break through the darkness and win the final victory. 


\section{CONCLUSION}

The aim of music appreciation class is to make college students understand the connotation of music works by studying the internal structure of music and its related content, understand composer's insight of the world and his profoundly "experience". We hope students can explore the "meaning" expressed by the music, improve the students' aesthetic consciousness and the mental state. So, the starting point and foothold of music quality education is that we should explain human's vision of the ideal, life struggle and sacrifice in Beethoven's symphony from the angle of improving college students' aesthetic quality.

\section{REFERENCES}

[1] [1] Minwang Yang. New World Famous Music Appreciation [M]. Shanghai: Shanghai Music Publishing House, 2009.

[2] [2] Etis Aja. [Britain]. Beethoven [M]. Nanjing: Jiangsu People's Publishing House, 1999.

[3] [3] Yingping Zhu. Innovation and Practice of University Music Appreciation Course Content Setting [J]. China's Adult Education, 2010.

[4] [4] Yue Guan. How to Embody Argument in University Music Appreciation Course [J]. Explore Music, 2011.1 